\title{
Summary of Thomson-Scattering Data From the Tandem Mirror Experiment (TMX)
}

\author{
K. K. Goodman
}

Manuscript Date: January 11, 1982

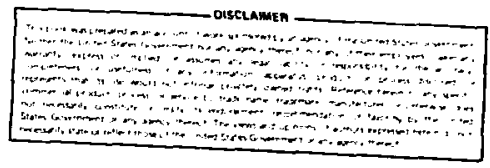

\section{LAWRENCE LIVERMORE LABORATORY} University of California $\bullet$ Livermore, California $\bullet 94550$ 


\title{
Summary of Thomsori-Scattering Data From the Tandem Mirror Experiment (TMX)
}

\begin{abstract}
We provide a synthesis of our Thomson-scattering measurements of electron temperature $\left(T_{c}\right)$ and density $\left(n_{c}\right)$ for the Tandem Mirror Experiment (TMX). TMX operated in two modes-high and low $T_{\mathrm{e}}$. When performing in the high $\mathrm{T}_{\mathrm{e}}$ mode (in general $>100$ eV), heating the central-cell ions with neutral beams raised $T_{e}$ in the end plug. We achieved a maximum $T_{e}$ of $260 \mathrm{eV}$ in the east end plug. Specifically, our experiments demonstrated that in the end plug, the radial $T_{c}$ profiles were flat to $\mathrm{r}=5 \mathrm{~cm}$; the ratio of potential $\left(\phi_{p}\right)$ to $T_{e}$ ranged between four and six. In addition, we found that although $T_{e}$ in the central cell was generally comparable to that in the plug, it was often not constant along a magnetic field line. Under some conditions a non-Maxwellian electron distribution may have been present.
\end{abstract}

\section{Introduction}

This final report on Thomson-scattering summarizes the electron temperature $\left(T_{1}\right)$ and density (n.) data gained from the wo Thomson-scatiering systems used on the Tandem Mirror Experiment (TMX), a machine that uperated at Lawrence Livermore National Laboratory (LLNL) from 1979-80. A detailed description of the electron power flow for a few well-documented operating condítions, based on these Thomson-scattering measurements has heen previously described by Grubb.

The TMX ${ }^{i}$ consisted of a long central cell or solenoid plugged at each end by minimum-B mirror colls (Fig. 1). High-density plasmas were main. tained in the end plugs by the injection of neutral beams at energies hetween 15 and $18 \mathrm{keV}$. (For sonle experiments a small amount of higher-energy beam current-approximately 32 $\mathrm{keV}$-was also injected into the plugs.) A plasma with lower energy and density was contained in the central cell. This central-cell plasma was fueled hy gas input either from the tiro gas boxes located near the transition coils or from the puffer located on the central-cell midplane.

Whereas the TMX proposal " predicted a $T_{\text {. }}$ of $20 \mathrm{C} \mathrm{eV}^{\prime}$ in the end plugs, during the actual operation of TMX we achieved above $200 \mathrm{eV}$ cn $15 \mathrm{oc}$ casions (see Table 1). We place the "official" high-electron temperaturc in the plugs at $260 \mathrm{eV}^{3}$ although there were two even higher shots. We have confidence in this $260 \mathrm{eV}$ value, considering the probable errors in the measurements. However, as discussed below: TMX did not always achieve these high-electron temperatures, and $T$. was nut always constant along magnetic field lines.

There were two independent Thomsonscattering systems on TMXN-one located on the midplane of the east end plug. and nother located on the midplane of the central cell (Fig. 2). We could medsure with the east-plug system at radial positions of $r=0,5,10$, and $15 \mathrm{cr}$. This s) stem was in use during the entire operation of TMIX. The central-cell system, which could measure al only $r=0 \mathrm{~cm}$, was installed shortly before the shutdown of TMX. Thus, a very limited amount of data is avajlable from the centra.-cell sy'tem, and we must base many of our conclusions on the information gained from the instrument on the east end plug.

The electron temperature, obtained with a given amount of input neutral-beam power, can be greater in one end plug of a tandem mirror than in a single mirror. In fact, the TMX east end plug often achieved electron temperatures three to four times higher than those of 2XIIB (a similar single-celi mitrot machine that operated at LLNL from 1976-78) when 2 XIIB operated with neutral-beam input power comparable to one of the $T M X$ end plugs. Since TMX had a large-volume plasma in the central cell, such an increase in $T$. indicates a hundredfold improvement in electron energy confinement. ${ }^{\prime}$ This escalation was possible because of two conditions: the TMX central cell supplied the low-energy 

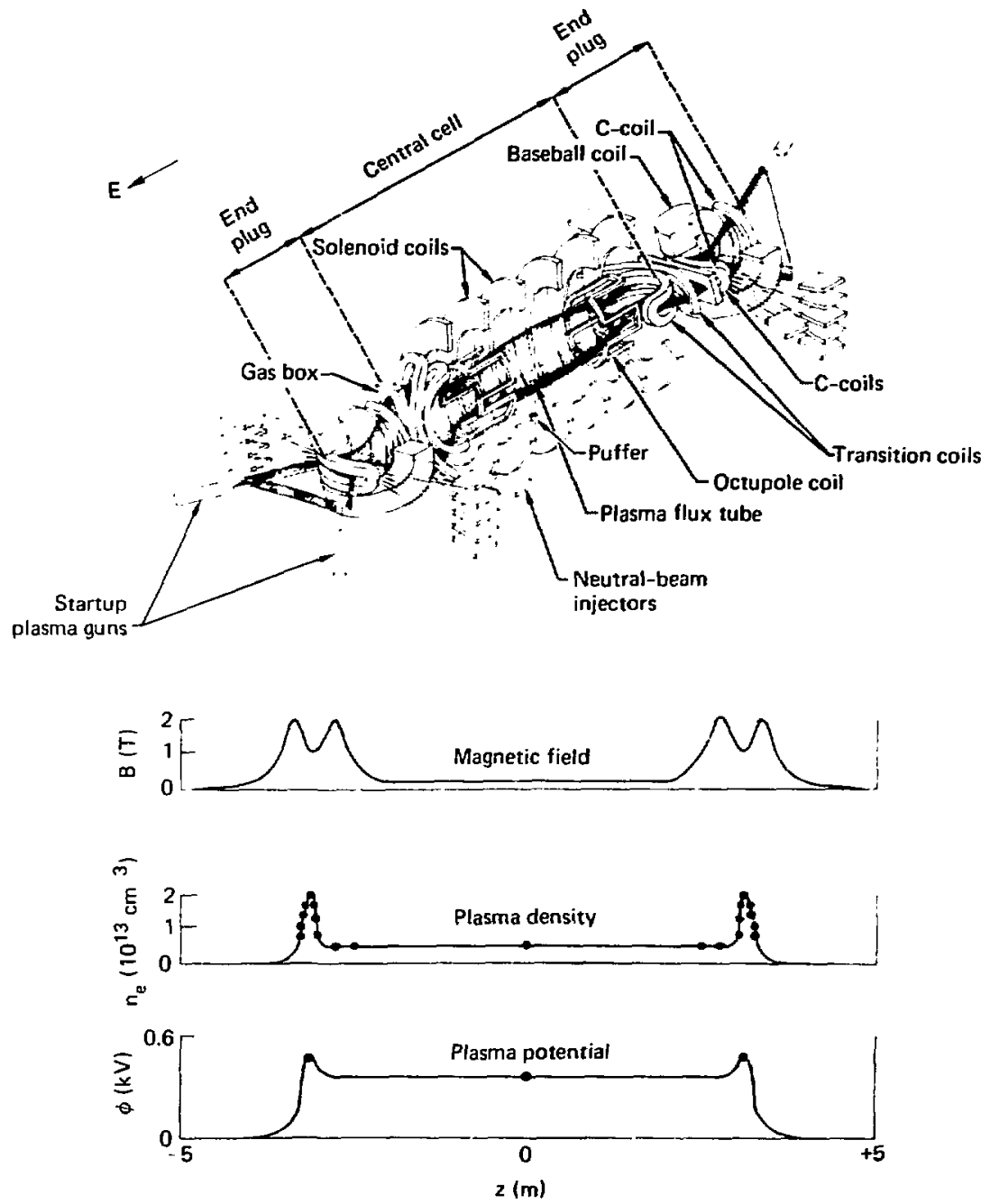

Figure 1. TMX magnet geometry and axial profiles. 
Table 1. Summary of TMX electron temperature $\left(T_{c}\right)$ measurements $>150 \mathrm{eV}$.

\begin{tabular}{|c|c|c|c|c|c|c|c|c|c|c|c|}
\hline Date & Shot no. & $T_{f}(c V)$ & Date & Shot no. & $T_{\text {ef }}(\mathrm{eV})$ & Date & Shot no. & $T_{q}(\mathrm{eV})$ & Date & Shot no. & $T_{e}(e V)$ \\
\hline \multirow[t]{3}{*}{7.20 .79} & 10 & 162 & 9.28 .79 & 57 & 172 & $12-5-79$ & 32 & 179 & $5-27-80$ & 6 & 173 \\
\hline & 18 & 166 & & 58 & 164 & & 34 & 184 & & 64 & 151 \\
\hline & & & & 59 & 155 & & 35 & 199 & & & \\
\hline \multirow[t]{2}{*}{$7.25-79$} & 27 & 171 & & & & & 45 & 220 & $7-9.80$ & 27 & 232 \\
\hline & & & $10-5-79$ & 22 & 170 & & & & & 28 & 159 \\
\hline \multirow[t]{5}{*}{$9=17-79$} & 22 & 219 & & & & $12-6-79$ & 27 & 162 & & 30 & 172 \\
\hline & 27 & 187 & $10-9.79$ & 9 & 167 & & 32 & 177 & & & \\
\hline & 28 & 157 & & 15 & 164 & & 40 & 151 & $7-18-80$ & 49 & 155 \\
\hline & 29 & 182 & & & & & 70 & 155 & & & \\
\hline & & & $11 \cdot 5.79$ & 10 & 200 & & & & $8-14 \cdot 80$ & 10 & 190 \\
\hline \multirow{4}{*}{$9-21-79$} & 35 & 273 & & 11 & 164 & $12-11-79$ & 29 & 152 & & 11 & 199 \\
\hline & 43 & 152 & & 12 & 196 & & 34 & Ib4 & & 39 & 341 \\
\hline & 4t & 192 & & 14 & 191 & & 37 & 171 & & & \\
\hline & & & & 15 & 170 & & 40 & 159 & $8-18-80$ & 24 & 185 \\
\hline \multirow[t]{5}{*}{$9-25-79$} & 13 & 154 & & 62 & 196 & & 42 & 159 & & & \\
\hline & 54 & 166 & & & & & 48 & 178 & $8-19-80$ & 8 & 156 \\
\hline & 55 & 209 & $11-21-79$ & 30 & 163 & & 53 & 196 & & 37 & 153 \\
\hline & 57 & 292 & & 34 & 165 & & 54 & 195 & & 16 & 227 \\
\hline & & & & 35 & 163 & & 55 & 174 & & 49 & 166 \\
\hline \multirow[t]{6}{*}{$9-26-79$} & 16 & 229 & & 36 & 163 & & & & & 50 & 176 \\
\hline & 17 & 174 & & 38 & 176 & $12-12-79$ & +1 & 162 & & 54 & 152 \\
\hline & 22 & 260 & & 42 & 169 & & & & & 63 & 167 \\
\hline & 35 & 155 & & $\$ 3$ & 187 & $12-13-79$ & Bo & 15; & & 68 & 194 \\
\hline & 55 & 153 & & & & & BI & 168 & & 69 & 244 \\
\hline & & & 11.27 .79 & $\$ 0$ & 162 & & & & & 87 & 172 \\
\hline \multirow[t]{11}{*}{$9-28-79$} & 22 & 194 & & 51 & $16 B$ & $2-7-80$ & 23 & 176 & & 9.7 & 204 \\
\hline & 29 & 187 & & & & & 24 & 156 & & 45 & 177 \\
\hline & 36 & 182 & $11-28.79$ & 49 & 156 & & 26 & 222 & & 96 & 173 \\
\hline & 38 & 189 & & 51 & 156 & & & & & 97 & 163 \\
\hline & 39 & 188 & & & & 2.8 .80 & 14 & 161 & & 98 & 224 \\
\hline & 43 & 173 & $11-30-79$ & 20 & 174 & & & & & & \\
\hline & 48 & 206 & & 40 & 197 & $3-28-80$ & 19 & 170 & 8.22-80 & 44 & 190 \\
\hline & 50 & 158 & & 41 & 171 & & & & & 71 & 177 \\
\hline & 51 & 156 & & +2 & 177 & $5-73.80$ & 43 & 157 & & & \\
\hline & 52 & 169 & & 44 & 189 & & 59 & 189 & & & \\
\hline & 53 & $: \$ 2$ & & 47 & 213 & & & & & & \\
\hline
\end{tabular}

All measurements were in the east plug at radius $20 \mathrm{~cm}$. 


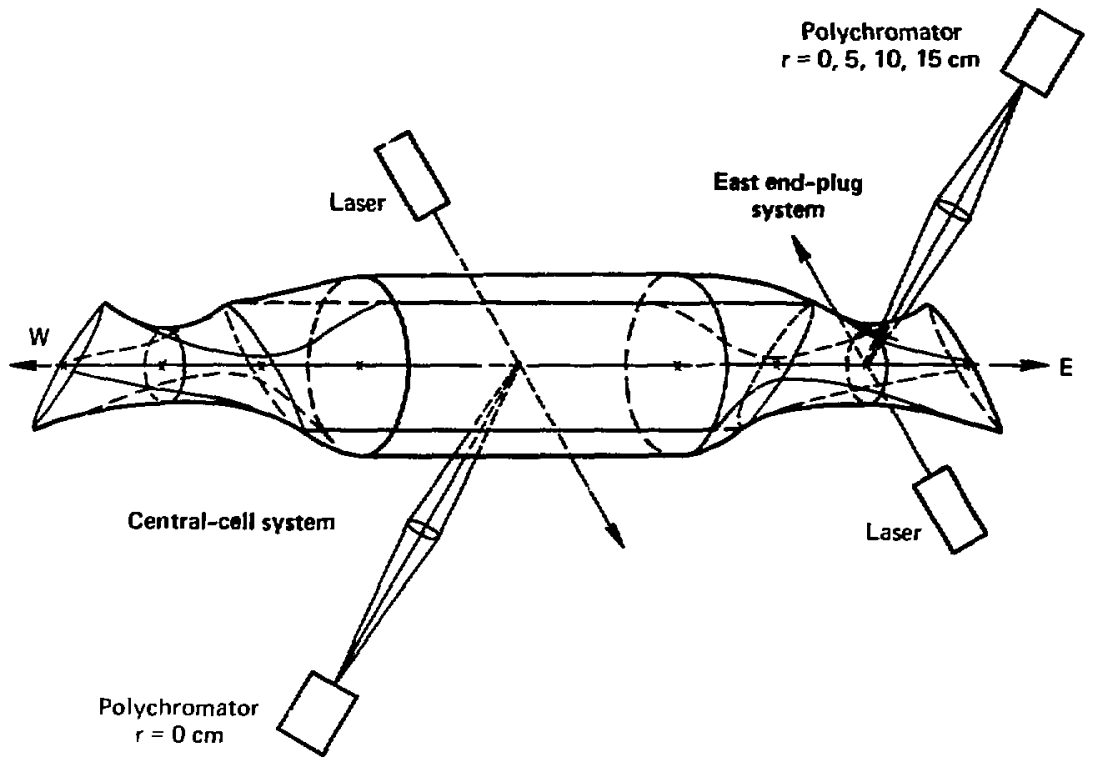

Figure 2. Location of the two TMX Thomson-scattering systems on TMX with respect to the magnetic field lines. Polychromators and lasers are two of the components of each system.

plasma required for end-plug microstability, and the plasmas were decoupled from the end walls of the plitgs."

TMX had two general modes of operating: one was the high $T_{\text {, }}$ mode (in general $>100 \mathrm{eV}$ ) described above, and the second was a lower $T_{\text {. }}$ mode in which the $T_{r}$ scalings were close to those observed in the 2XllB experiment. Table 1 lists all TMX shots in the plug with a $\mathrm{T}_{\mathrm{c}}$ above $150 \mathrm{eV}$. These shots occurred for various combinations of experimental operating parameters such as beam current, gas fueling, and magnetic field.

While it was not always completely clear what caused the experiment to operate in the high and low modes, several mechanisms have been tnntatively identified. TMX was observed to drop from the high $T_{p}$ to the lower $T_{e}$ mode when the central cell received too much fueling gas from either the gas boxes or the central-cell puffer. Also, a vacuum leak in the west-plug ragion caused lower electron temperatures in the east plug. (For details see the following sections on Electron Temperature Scaling and the Comparison of Temperature Measurements in the Plug and Central Cell.) These results, along with observations by Pickles, (as reported by Correll ${ }^{4}$ and the TMX Group ${ }^{19}$ ) indicate that ultimately, $T_{e}$ was dependent upon vacuum conditions.

This summary report employs 18 repiesentative figures to depict the pertinent data gathered by the twis Thomson-scattering systems on TMX. As approprate, we have compared our findings to those of single-cell mirrors. In the final section we summarize the information we will apply to our next-generation machine, TMX Upgrade. This new experiment will begin operation in the spring of 1982 .

\section{Radial Profiles of Temperature and Density}

Radial profiles of the electron temperature $\left(T_{e}\right)$ in the east end plug are shown in Fig. 3 for 
both puffer and gas-box fueling. These data are from shot-by-shot scans taken during operation in a high $T_{\text {a }}$ mode. Note that in this figure the gas-box profile is relatively flat to $r=5 \mathrm{~cm}$; in contrast, the puffer profile has dropped slightly at $5 \mathrm{~cm}$. Both profiles drop sharply between 5 and 10 $\mathrm{cm}$. We also checked at $15 \mathrm{~cm}$, but there was not enough plasma at that radius to measure.

Figure 4 illustrates radial profiles of both $T_{\text {e }}$ and density $\left(n_{\mathrm{e}}\right)$ in the plug and compares these with our $T_{w}$ and $n_{w}$ measurements in the central cell. The temperature and density points for each shot are paired vertically. For this scan, the plug measurements at $r=0$ and $5 \mathrm{~cm}$ were made simultaneously and are matched left-to-right. Because the plug system at $r=10 \mathrm{~cm}$ was not calihrated for density, those data are not available.

In this scan illustrating puffer fueling (Fig. 4), both $T_{\text {, and }} n_{i}$, are flat to $5 \mathrm{~cm}$. The error bars on each measurement are determined from fits to the scattered wavelength spectrum-measured by the photomultiplier tube (PM) channels-that are \pm a (standard deviation) from the best Gaussian fit. The staiistical o for each PM is measured after each shot and is used as a weighting factor in the fitting."

Radial measurements of density profiles in the east plug by other diagnostics show that $T_{0}$ scales radially as $\left(n_{i}\right)^{2}$."

\section{Comparison of Temperature and Density Measurements Before and After Beam Turnoff}

Experiments were conducted in which neutral beams in the cast plug were turned off earlier than those in the west end [Fig. 5(a)]. Note that

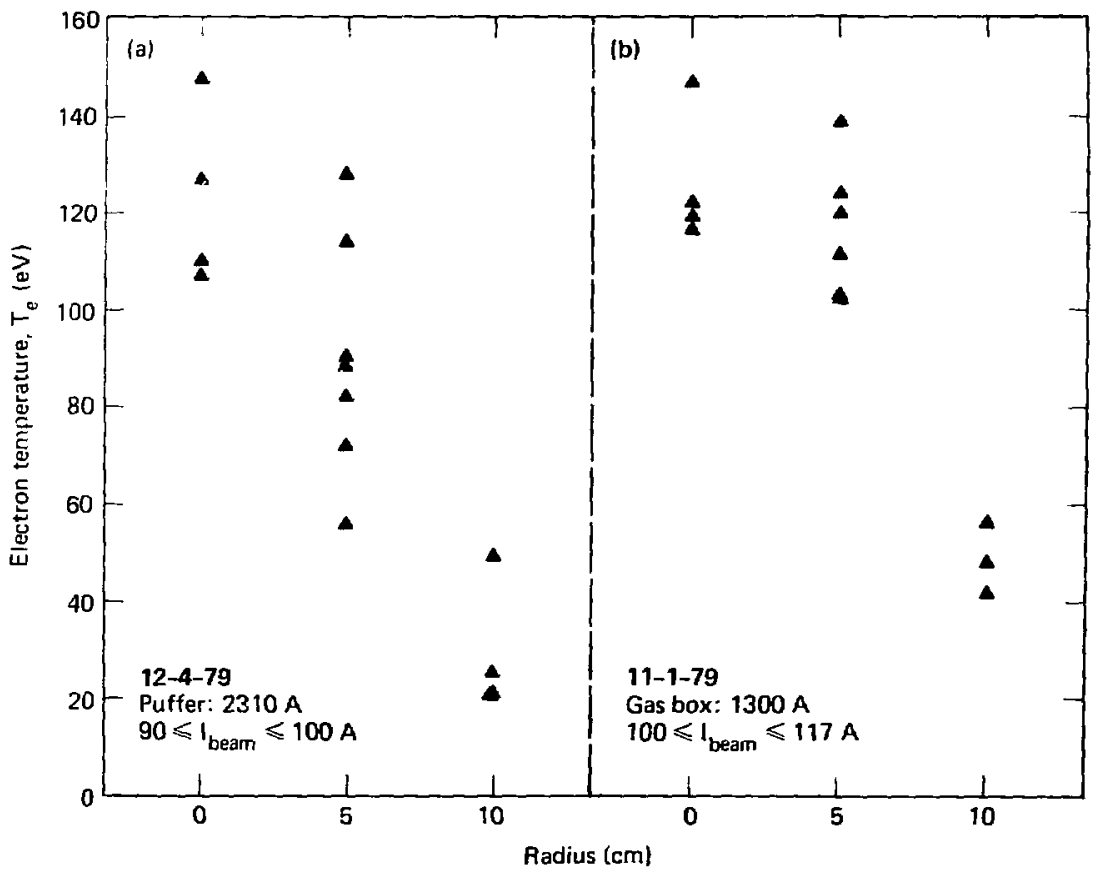

Figure 3. Radial profiles of the east-plug electron temperature $\left(T_{\mathrm{e}}\right)$ contrasting gas fueling by (a) the puffer in the central cell with (b) the gas boxes near the transition coils. 


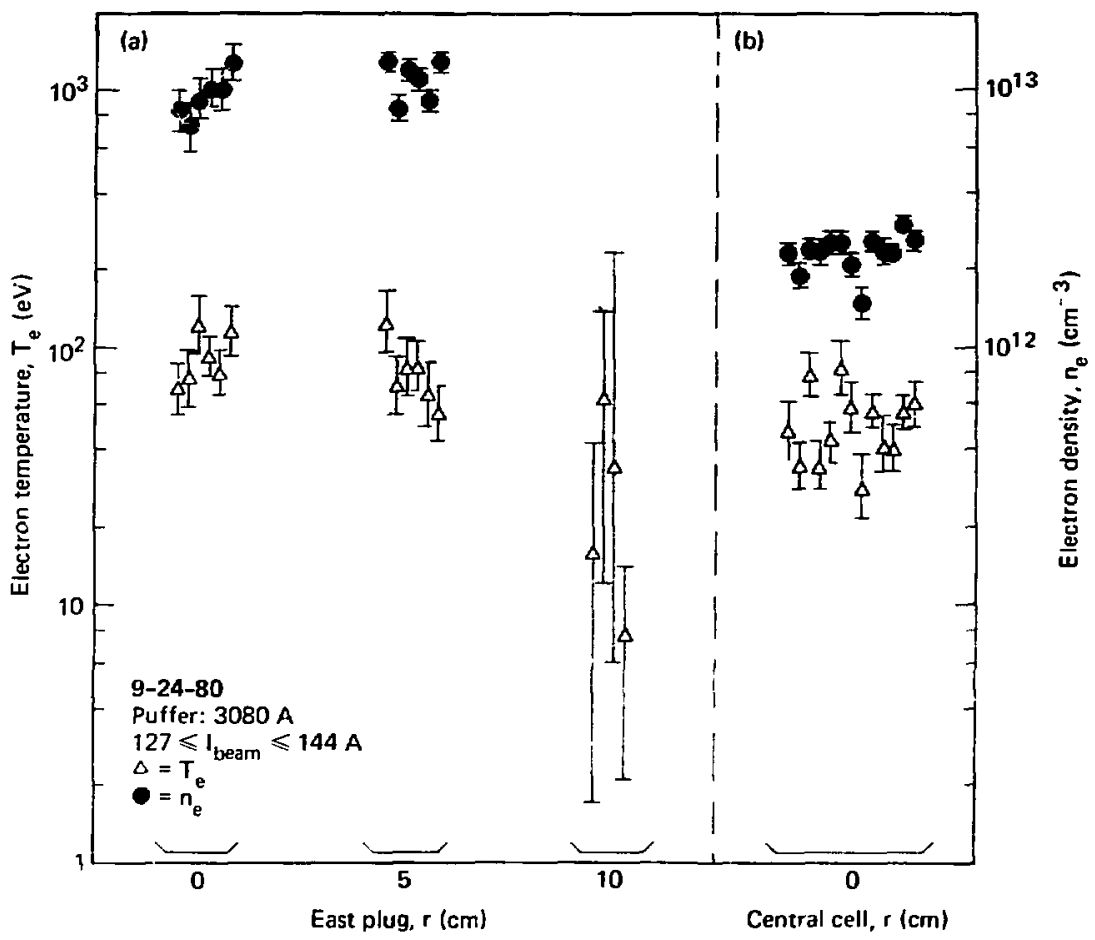

Figure 4. Radia: profiles of (a) east-plug electron femperature ( $\left.T_{e}\right)$ and density $\left(n_{e}\right)$ compared to (b) central-cell measurements for indicated values of puffer fueling and neutral-beam heating. To avoid overlapping data, measurement ( $T_{\mathrm{e}}$ ) points were offset.

density $\left(n_{e}\right)$ in the east plug $(r=0 \mathrm{~cm})$ begins to drop within $1 \mathrm{~ms}$ of the east beam turnoff. However, at the same time the electron temperature $\left(T_{6}\right)$ has not changed; this implies that the plug potential $\left(\phi_{\mathrm{f}}\right)$ is also still high. At $5 \mathrm{~ms}$ after beam turnoff, $n_{\mathrm{e}}$, has continued to drop, and $\mathrm{T}_{\mathrm{e}}$ has also dropped considerably.

The results of this temporal behavior of $T_{\text {e }}$ and $n_{c}$ can bf seen in the current lost from the east end [Fig. 5(b)], as measured by an end-loss analyzer. ${ }^{12}$ Most of this end-loss current can be traced to escaping central-cell ions. In the steadystate operation of the east plug $(t=10$ to $15 \mathrm{~ms})$, the $\phi_{p}$ is greater than the central-cell potential $\left(\phi_{c}\right)$, and the central-cell ions are electrostatirally confined. At 1 ms after beam tumoff, $T_{r}$ (and presumably $\phi_{F}$ ) has not changed, although $n_{e}$ has begun to decrease. The central-cell ions are still confined, and the end-loss current has dropped because if nuctuation levels have decreased. ${ }^{13.14}$ After $3 \mathrm{~ms}$. $T_{\text {.e }}$ diops, and $\phi_{p}$ is no longer high enough to confine the centrat-cell ions; this causes a large end-kss current. This $T_{e}$ data corroborates other evidence for the plugging effert of a tandem mirror $_{r}^{3.15}$

Figure 6 shiows shot-by-s'.lot radial profiles of $T_{e}$ for a similar experiment in which the east-plug beams were terminated at $t=24 \mathrm{~ms}$ and the 

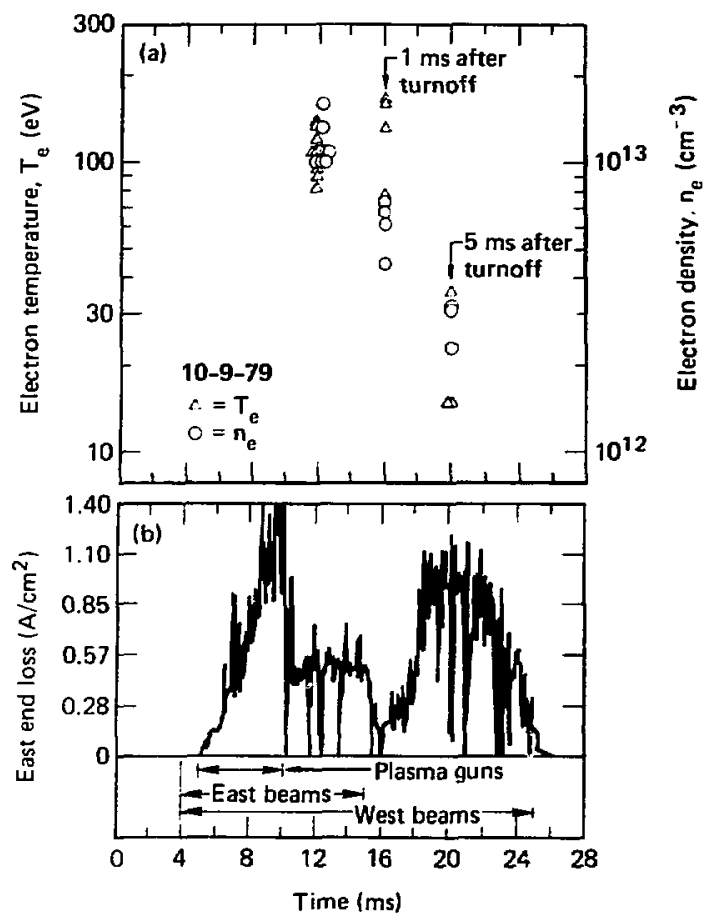

Figure 5. Comparison of (a) time variation of east-plug electron temperature $T_{r}$ and $n_{e}$ to $(b)$ loss of current from the east end plug density. The radius is $0 \mathrm{~cm}$.

west-plug beams at $t=28 \mathrm{~ms}$. At $r=0$ and $5 \mathrm{~cm}$.

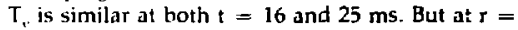
$10 \mathrm{~cm}$. T. at $25 \mathrm{~ms}$ has dropped from its steadystate value. This fall demonstrates that after the input pow'er to the plasma is terminated, electrons located at larger radii lose energy more rapidly than those in the core of the plasma. As in the previous experiment (Fig. 5), $n_{\mathrm{c}}$ at $r=0 \mathrm{~cm}$ has already dropped a factor of three at $1 \mathrm{~ms}$ after beam turnoff.

We now tum to our experiments dealing with $T$, alone as well as those that concern potential and distribution.

\section{Electron Temperature Scaling}

In an experiment using constart gas fueling by the pulfer (1540 A equivalent), the electron temperature $\left(T_{\mathrm{C}}\right)$ in the plug $(\mathrm{r}=0 \mathrm{~cm})$ was measured while the input beam currents ( $i_{\text {busm }}$ ) to the plugs were varied. In Fig. 7 we have plotted these

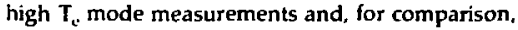
the same measurements (under similar conditions) from $2 X I I B$. The electron temperature in the single-cell $2 X I I B$ was proportional to $I_{\text {heam, }}$, whereas in $T M X$ it was independent of $I_{\text {hism }}$ for the high mode. In addition, $T_{e}$ in $T M X$ was several 


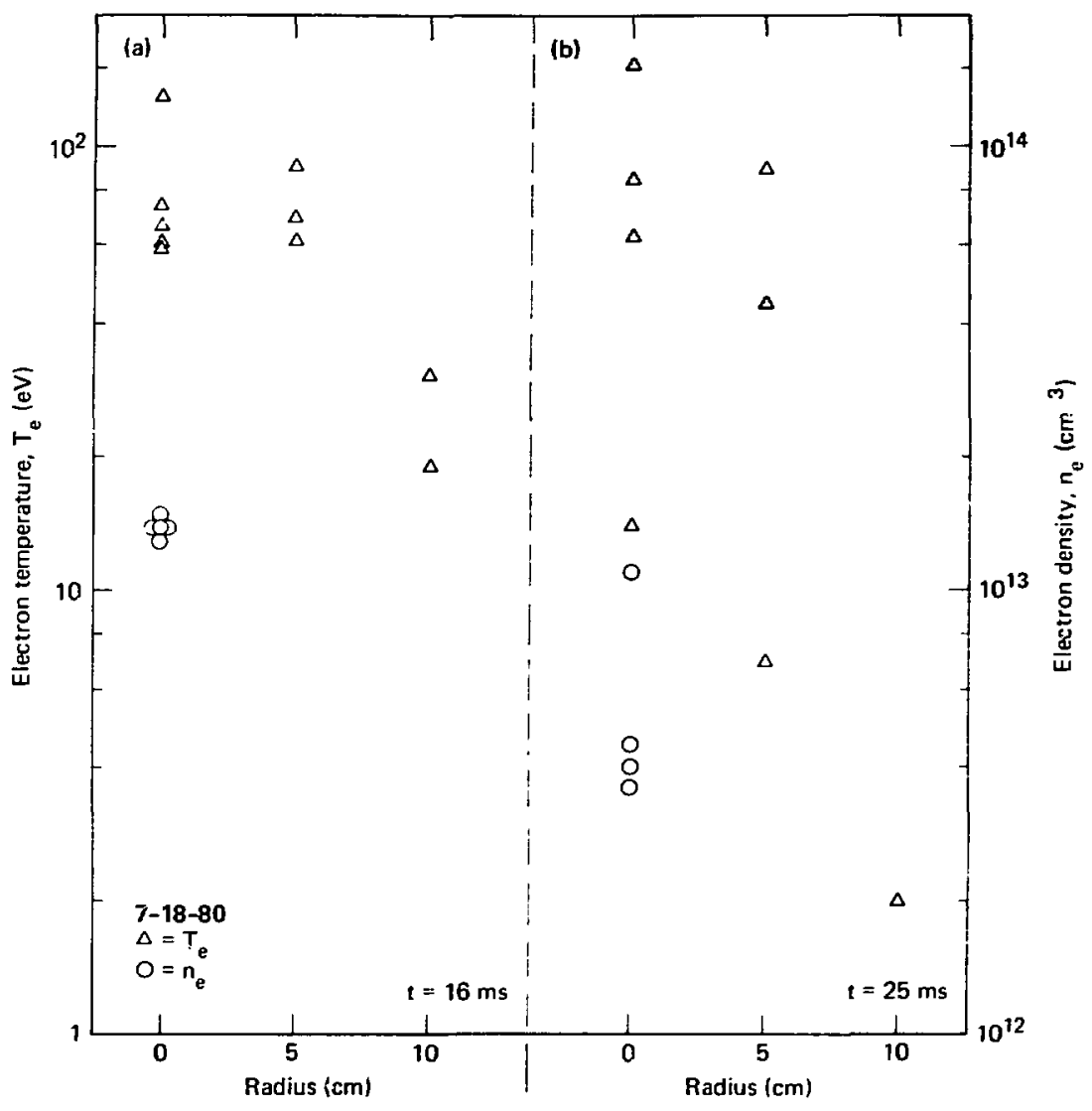

Figure 6. East-plug radial profiles of electron temperatire (Te) at (a) $16 \mathrm{~ms}$ vs $T_{e}$ at (b) $25 \mathrm{~ms}$. The east beams were turned off at 24 ms.

times higher than could be obtained in 2 XIIB with a comparable $I_{\text {beam. }}$.

These differences in $T_{e}$ scaling with $I_{\text {tram }}$ betiveen TMX and its forerunner, 2 XIIB, arise from the requirement of providing low-energy plasma to control the drift-cyclotron loss-cone (DCLC) instability in a minimum-B mirtor cell. In 2 XIIB, this low-energy plasma was ultimately supplied by the neutral-beam current, making $T_{e}$ proportional to $\mathbf{l}_{\text {trian }}{ }^{1 \text { th }}$ But in TMX, this stabilizing plasma for the end plugs was supplied by axial losses from the central cell, which allowed the plug $T_{e}$ to be independent of $\mathrm{I}_{\text {bedm. }}{ }^{13}$

Figure 8 indicates how the shift between the high and the low $T_{e}$ modes is caused by changes in the amount of fueling gas introduced into the central cell by the puffer. For this experiment on Sept. 17. 1979, all the other machine parameters 

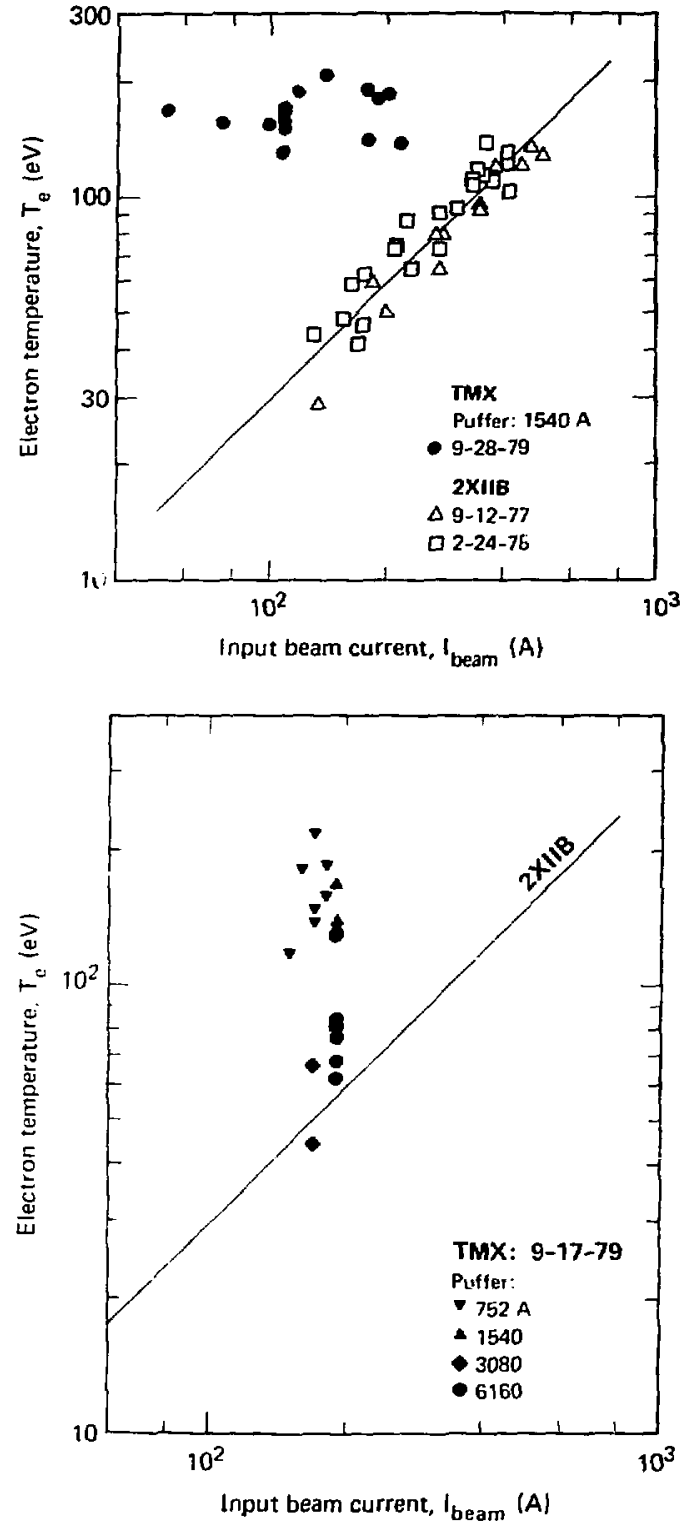

Figure 7. East-plug eleciron temperature $\left(T_{f}\right)$ vs east-plug beam current $\left(\mathrm{b}_{\text {besm }}\right)$. Measurements are compared with the same ones from the single-cell machine, $2 X I I B$, at $r=0 \mathrm{~cm}$.

Figure 8. Variation in electron temperature $\left(T_{e}\right)$ in the east plus $(\mathrm{r}=0 \mathrm{~cm})$ as the gas fueling from the central-cell puffer was increased. 
were held constant. Thus, we can see that large amounts of fueling gas can restrict $T_{e}$ in the TMX plug to the $2 X I I B$ regime. Operation of TMX near the 2 XIIB scaling suggests that, under these conditions, the central-cell axial losses are not providing the low-energy plasma necessary to stabilize the DCLC in the plug. However, on other occasions the TNX plugs operated near the 2 XIIB scaling regardless of the amount of gas introduced. TMX researchers have concluded that this was probably related to vacuum conditions in the ma. chine. ${ }^{10}$

\section{Comparison of Temperafure Measurements in the Plug and Central Cell}

To determine if $T_{e}$ was constant along magnetic field lines, we compared simultaneous measurements of temperature in the east end plug and the central cell. In Fig. 9 we have contrasted plug and central-cell $T_{e}$ at $r=0 \mathrm{~cm}$ for various $T M X$ operating conditions. TMX was running in the lower $T_{e}$ mode for most of these shots. Overall,

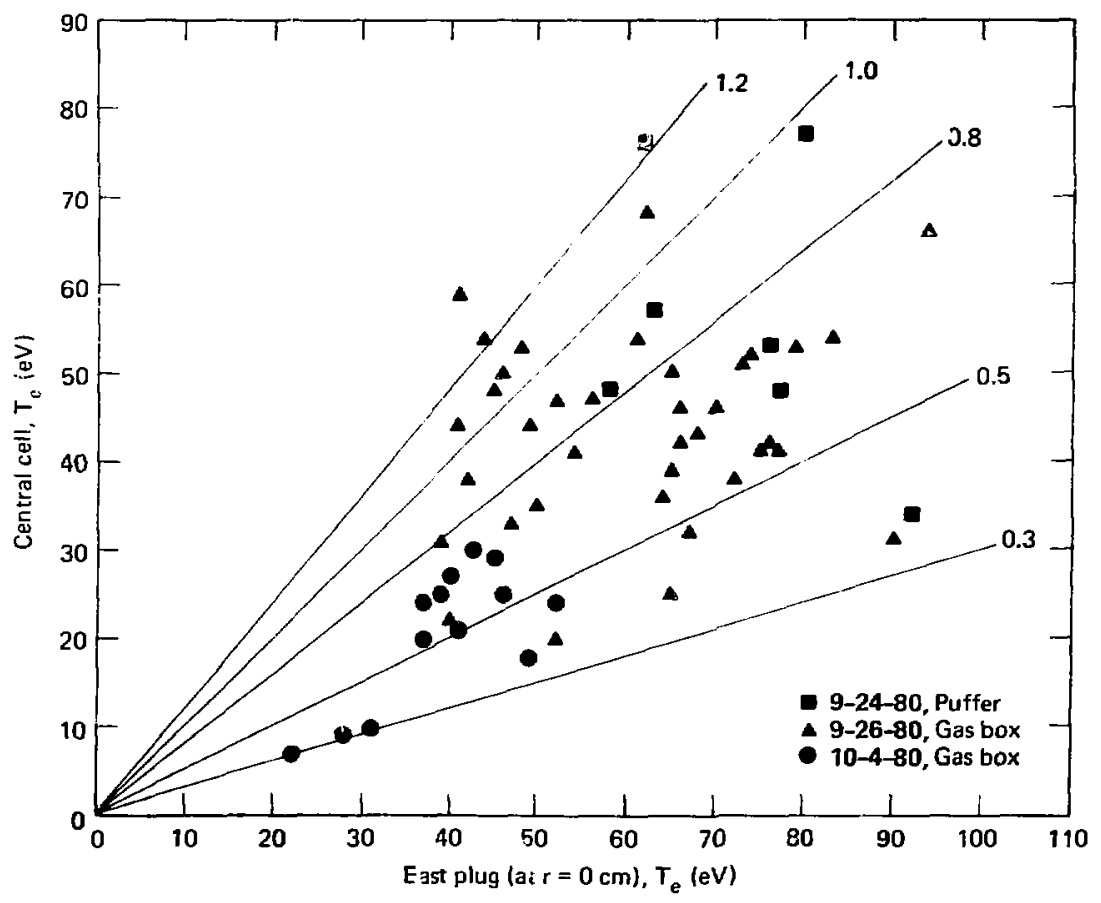

Figure 9. Comparison of simultaneous electron temperature measurements in the east plug ( $r=0$ $r$ i) and the central cell under various TMX ofrerating conditions. The diagonal lines show ratios of te (central cell) to $T_{e}$ (plug). 
central-cell $T_{e}$ is comparable to that in the east plug. The enistence of central-cell temperatures above $50 \mathrm{eV}$ indicates that there are no large energy losses due to impurities trapped in the central cell. ${ }^{17}$ Figure 9 also shows that the ratio of $T_{p}$ in the central cell to that in the plug can range from 0.3 to 1.2; thus, $T_{e}$ is often not constant along a given magnetic field line. This may be due to some isolation between plug and central-cell electrons that allows a gradient in the electron temperatures.

Figure 10 compares simultaneous east-plug and central-cell electron temperatures (at $r=$ $0 \mathrm{~cm}$ ), which were taken on the day (9-29-80) when one of the coils in the west plug developed a vacuum leak. As can be seen, this caused the east plug to drop from the high $T_{e}$ to the lower $T_{e}$ operating mode. Even with the resulting low temperatures, $T_{v}$ was usually not constant along a field line.
The radial profiles of $T_{e}$ at $r=0$ and $5 \mathrm{~cm}$ in the east plug and at $r=0 \mathrm{~cm}$ in the central cell are shown in Fig. 11 for the same shets as in Fig. 10. The tu mperatures at each position generally track each other. The point density profiles $\left(n_{r}\right)$ for these shots are given in Fig. 12 For comparison, the point densities obtained by unfolding linedensity measurements (Gaussian fits) from neutral-beam attenuation ${ }^{12}$ are also plotted. The rise in central-cell $n_{c}$ due to the air leak in the west plug can be seen; however, the east-plug densities are little affected by this rise and are relatively flat to a $5 \mathrm{~cm}$ radius. The higher rentral-cell densities are associated with the lower electron temperatures. This maximum centrnl-cell density is similar to the density that would result from a gas-box fueling of approximately $7000 \mathrm{~A}$ equivalent.

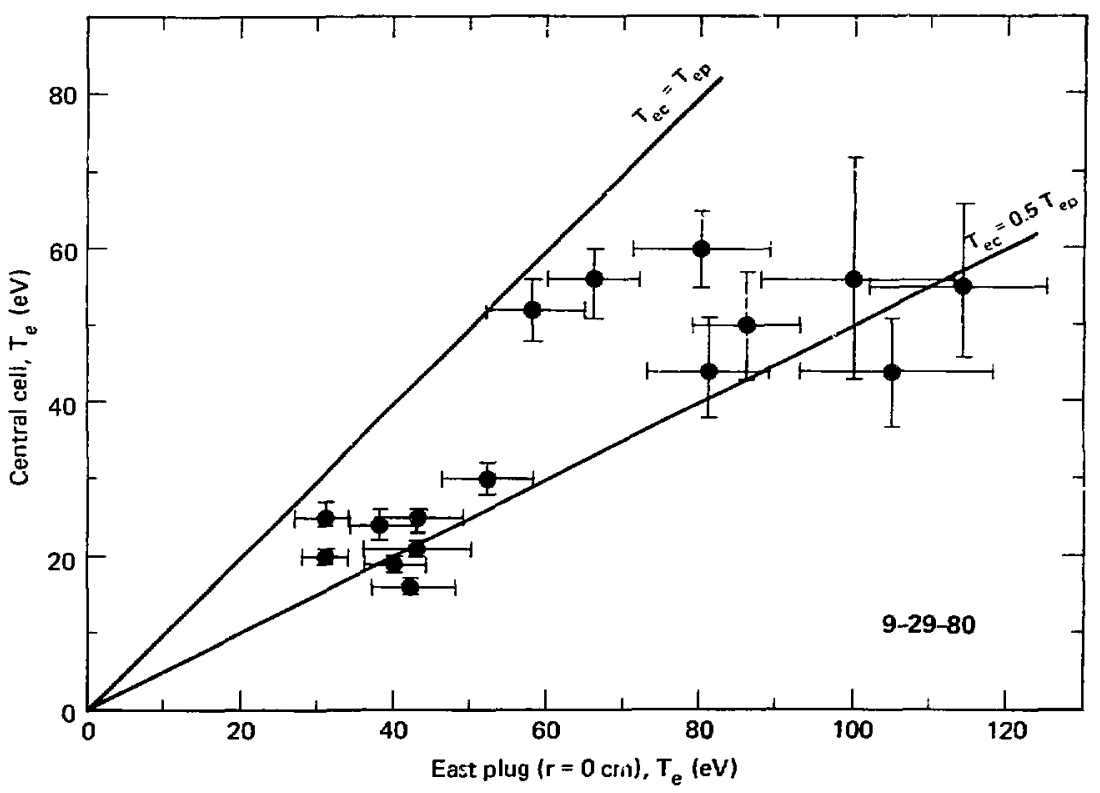

Figure 10. Comparison of simultaneous east-plug $\left(T_{e p}\right)$ and central-cell $\left(T_{e c}\right)$ electron temperature measurements with gas-box fueling only. The group of lower temperatures is associated with a vacuum leak in the west-plug region. 


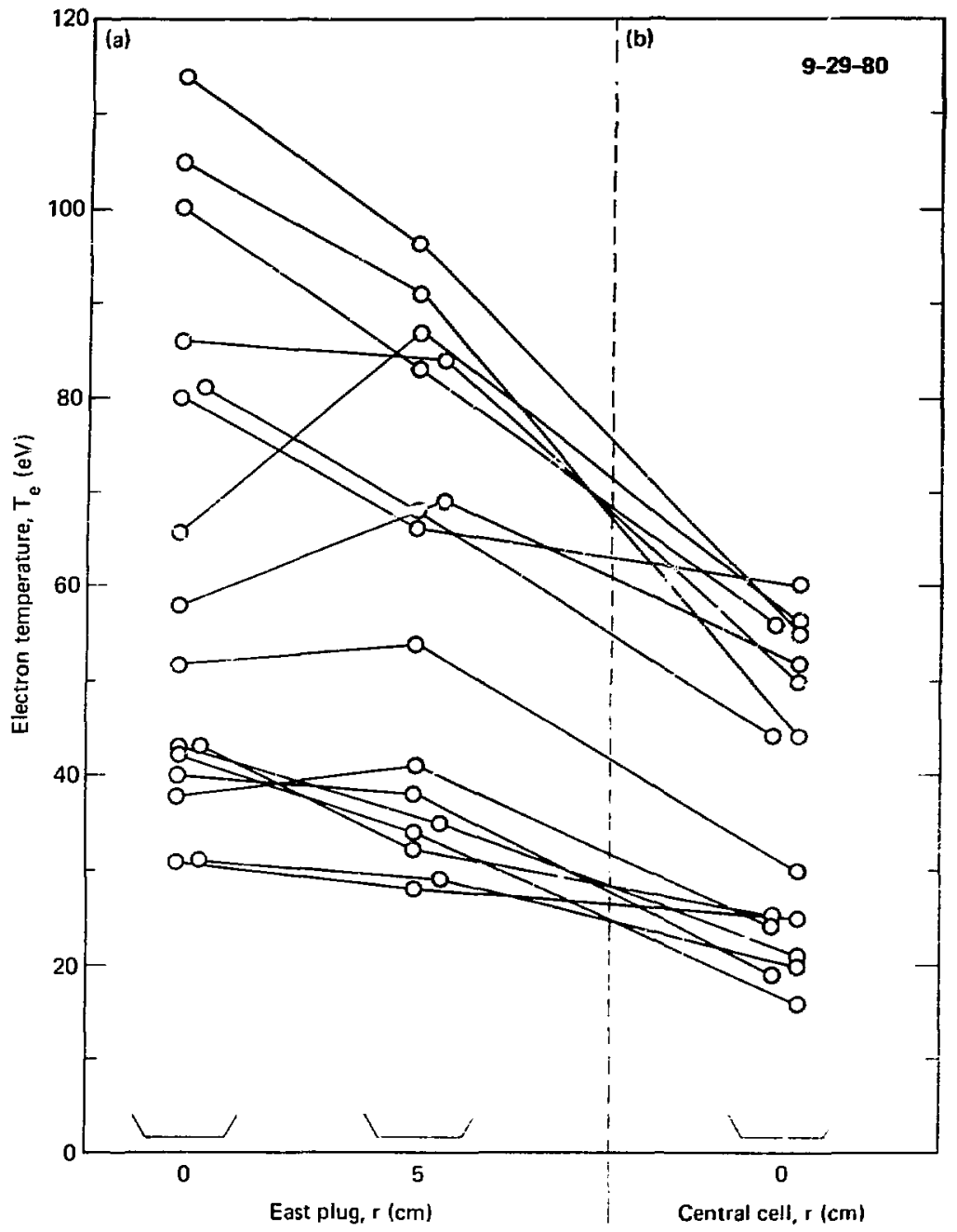

Figure 11. Electron temperatures $\left(r_{e}\right)$ at two radii in the (a) TMX east plug compared to (b) central-cell electron temperatures. The solid lines connect simultaneous measurements, although the points have been offset for ciarity. These data are for the same shols as Fig. 10. 


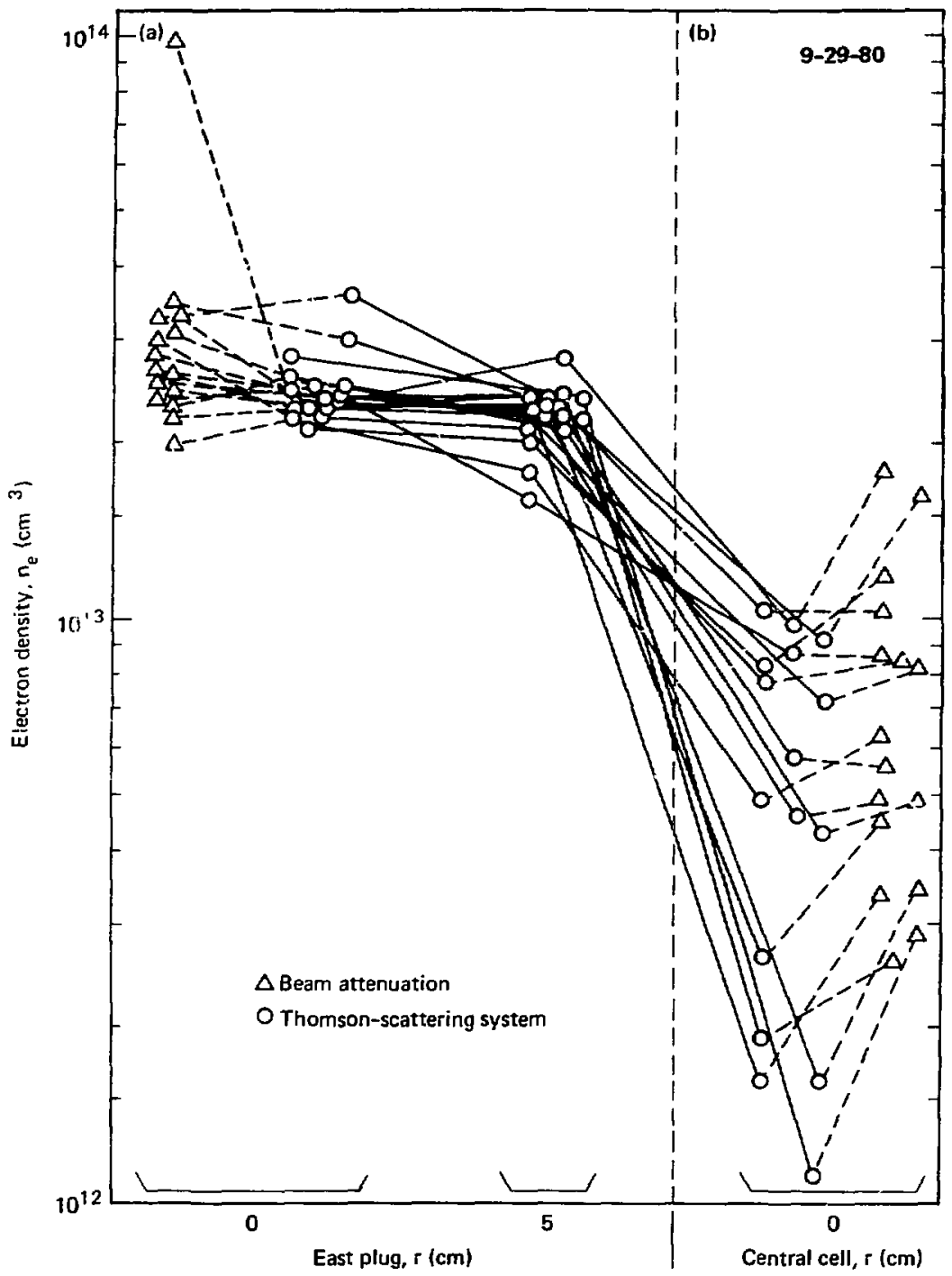

Figure 12. Plasma densities ( $n_{e}$ ) at two radii in the (a) TMX east plug compared to (b) central-cell densities. Also shown are densities obtained from beam-attenuation measurements. These data are for the same shots as Fig. 10; they are offset for clarity. The higher central-cell densities correspond to the lower electron temperatures of Fig. 11. 


\section{Effect of Central-Cell Beam Heating on Electron Temperatures}

We measured certain effects of heating the central-cell ions with neutral beams (Fig. 13). For this experiment we used a neutral-beam current between 45 and $60 \mathrm{~A}$ in the central cell, and a beam current in each plug between 110 and $140 \mathrm{~A}$. Under these conditions, $T_{e}$ in the east plug ir $=0$ $\mathrm{cm})$, which was in the high $T_{c}$ mode, was raised by the centrai-cell heating [Fig. 13(a)] as was the centra]-cell diamagnetic loop signal [Fig. 13(b)]. ${ }^{12}$ The second Thomson-scattering system was not installed in the central cell at this time. However, measurements by a vacuum ultraviolet spectrometer ${ }^{15}$ indicate that the central-cell $T_{\text {, }}$ was also raised by heating with neutral beams. ${ }^{\text {IN }}$
Figure 14 gives the results of a second centralcell heating experiment. Here. the gas fueling rate was also varied. The decrease in temperature in the east plug from the high $T_{\text {e }}$ to the lower $T_{\text {c }}$ mode, proportional to the increase in fueling rate. is evident. The heating is central-cell ions has little effect on the temperature in the plug when it is operating in the lower $T_{\text {, mode. }}$

\section{Correlation of Potential and Electron Temperature}

Radial profiles of the east-and-west-plug plasno potentials $\left(\phi_{p}\right)$, as measured by end-loss anal! zer: plus the east-plug electron temperature $\left(T_{\text {. }}\right)$ are plotted in Fig. 15 . This data is for the

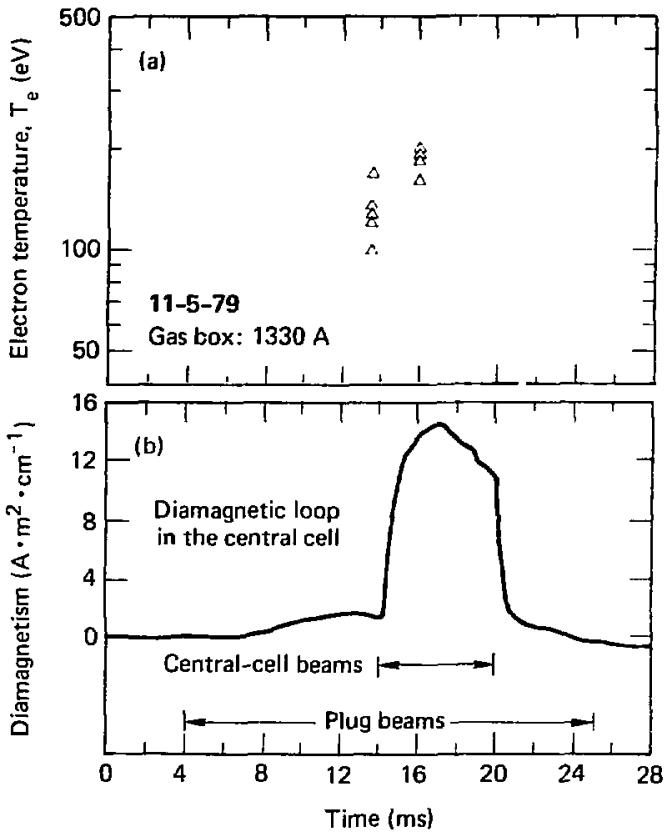

Figure 13. Some effects of neutral-beam heating of the central-cell ions including (a) analysis of east-plug ( $r=0 \mathrm{~cm}$ ) electron temperature before and during heating and (b) the central-cell diamagnetic loop signal (b). 


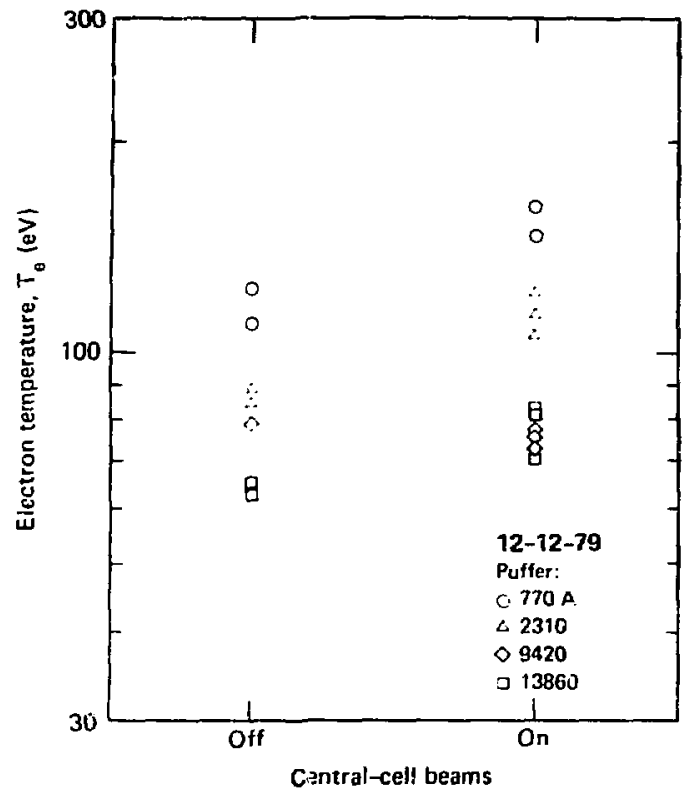

Figure 14. Analysis of east-plug $(r=0 \mathrm{~cm})$ electron temperalures with and without central-cell neutral-beam heating for four gas-fueling rales.

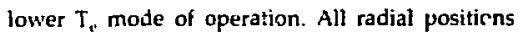
are plotted at an equivalent position or the plug midplane by mapping the magnetic field lines. Each point in this plot is an average over several snots, and the error bars represent the standard deviation. The east and west plugs have comparable plasma potentials, and the $\phi_{\mathrm{F}}$ and $\mathrm{T}_{\mathrm{c}}$ profiles have a similar shape.

A shot-by-shot comparison of the $\phi_{\mathrm{F}}$ and $T_{\mathrm{r}}$ in the east plug is given in Fig. 16 for two radii. Note that the low points are from the day (9-29-80) that a vacuum leak occurred in the west-plug region (see the preceding section on temperature measurements in the plug and central cell). Under these conditions the ratio of $\phi_{p} / T_{c}$ decreases to two; for normal operation, the $\phi_{p} / T_{e}$ ratio usually ranges between four and six at both $r=0$ and $5 \mathrm{~cm}$.

We also measured the central-cell plasma potential $\left(\phi_{c}\right)$ with the heavy-ion beam probe. ${ }^{12} \mathrm{Fig}$ - ure 17 shows a radial profile of $\phi$, compared to $T_{\text {r }}$ in roth the central cell and east plug using an averal fe over several shots. Here the central-cell radial positions are plotted at corresponding position : on the plug midplane. For these stots in the central cell, the ratio of $\phi_{c} / T_{e}$ at $r=0 \mathrm{~cm}$ is approxin'ately eight.

\section{Non-Maxvsellian Electron Distribution}

On some occasions the Thomson-scattered light spectra have shown what may be a non-Maxwellian electron distribution. Non-Maxwellian electron distributions have previously been observed in the Alcator experiment. ${ }^{19}$ Figure $18(a)$ is a single-shot, scattered light spectrum taken with the plasma in the central cell in equilibrium. The lines are weighted, least-square fits to the selected points, to form a 


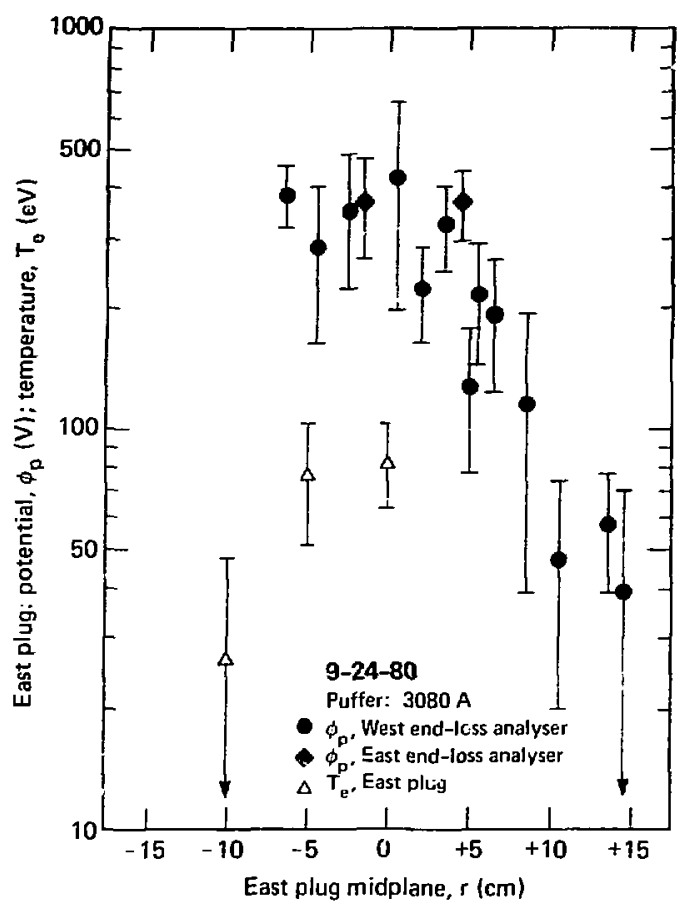

Figure 15. Radial profiles of the east-and-west-plug plasma potentials $\left(\phi_{p}\right)$ and the east-plug electron temperature $\left(T_{e}\right)$.

bi-Maxwellian distribution. Hese the evidence for a hot tail in the distribution function rests upon one point. Additional wavelength channels, which were not available when these data were taken, would be necessary to obtain more canclusive evidence. Hewever, for most shots the spectrum is best fitted by a single straight line that indicates a normal Maxwellian electron distribution,

As a further check for a nor. Maxwellian distribution, simultaneous east-plug and central-cell spectra are plotted in Fig. 18(b). These were taken $5 \mathrm{~ms}$ after the east-plug beams had been terminated and the plasma potential in the plug no longer blocked the central-cell ions. Under this condition the east plug and the central cell basically have a common plasma. These spectra show a relatively uniform electron temperature and density as would be expected. This also shows that the two Thomson-scattering systems have equivalent calibrations. The plug has a definite high-energy tail. and the central cell indicates one also.

Our measurements of central-cell potentials would match theory more closely if a higher energy tail were present on the central-cell electron distribution. ${ }^{20}$ While such an electron distribution is not definitely shown in our measurements, it would not be inconsistent with our data. 


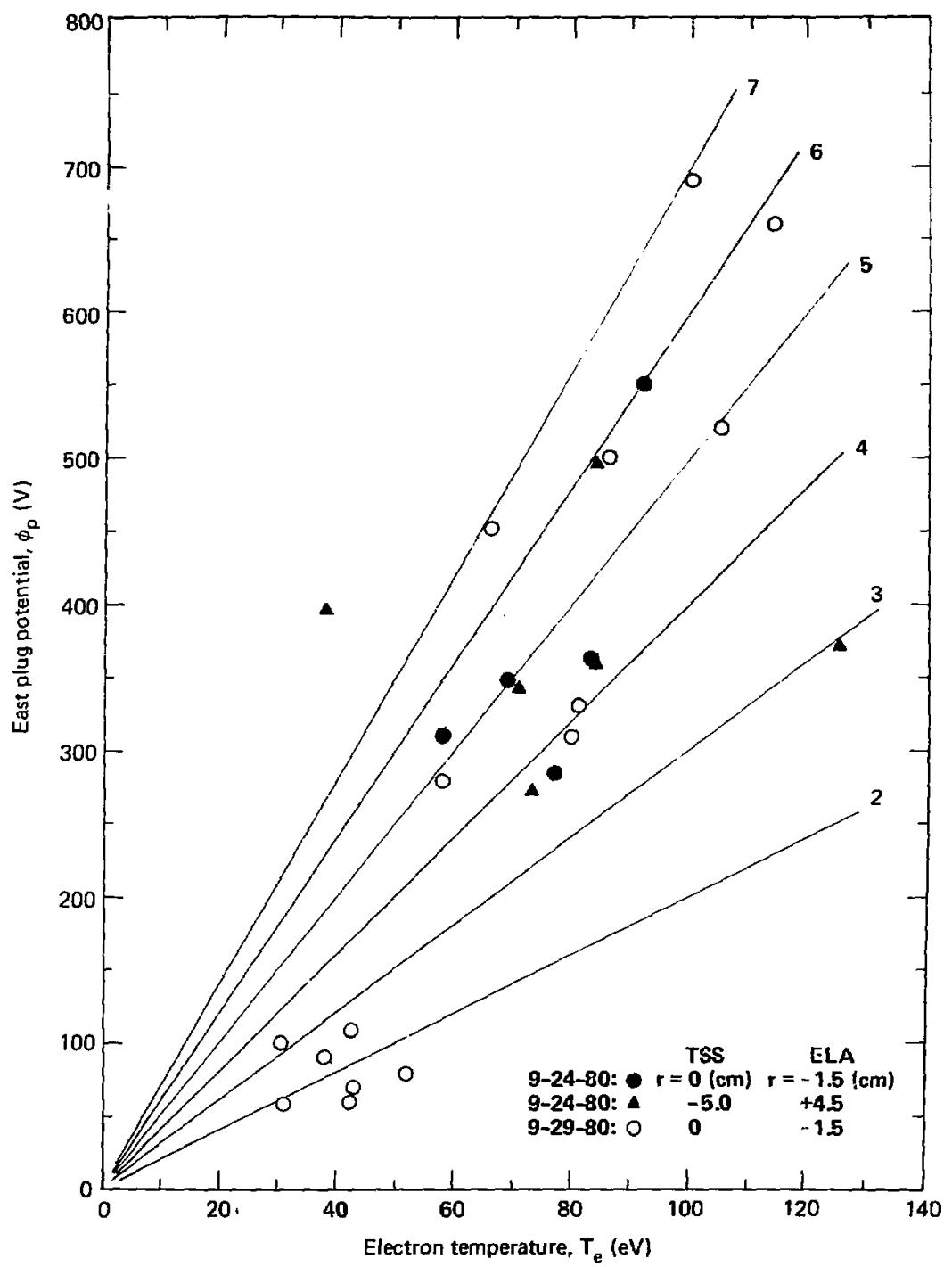

Figure 16. A shot-by-shot comparison of the east-plug electron temperature $\left(T_{e}\right)$ and plasma potential $\left(\phi_{p}\right)$ at two radii. The diagonal lines show the ratio of $\phi_{p} / T_{e}$ (TSS $=$ Thomson-scattering system; ELA $=$ end-loss analyzer). 


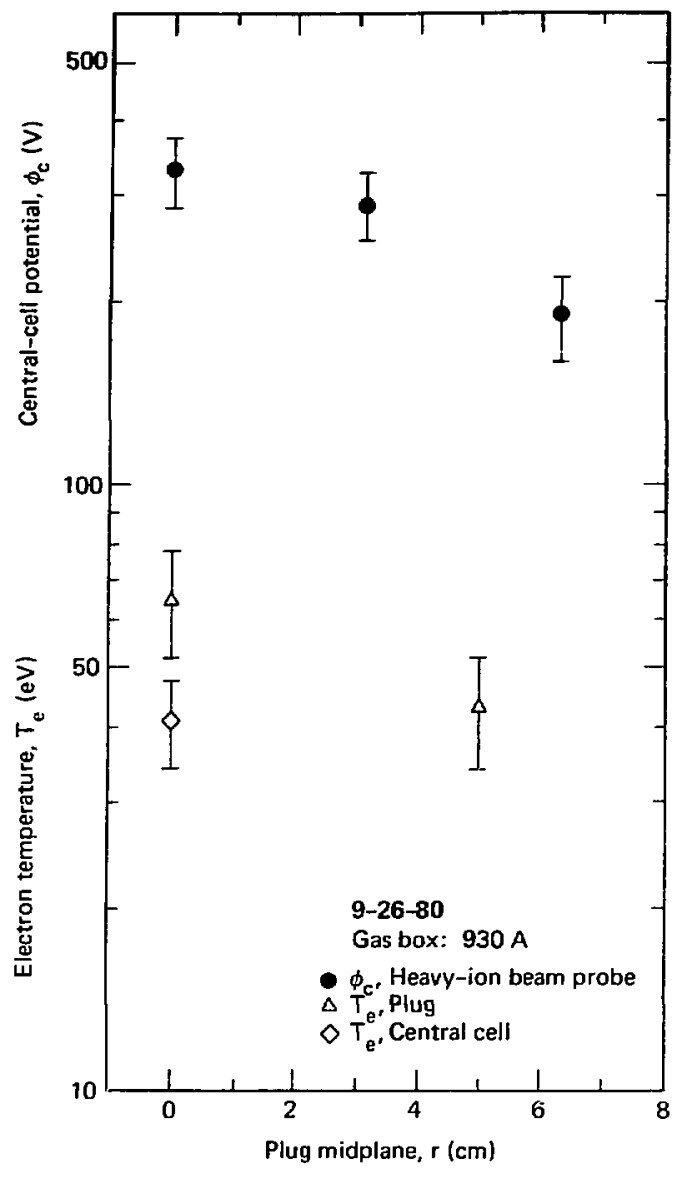

Figure 17. Comparison of the central-cell plasma potential $\left(\phi_{c}\right)$ and the plug and central-cell electron temperatures.

\section{Summary}

Our Thomson-scattering measurements show that the TMX end plugs can uperate in two electron temperature modes: a high $\mathrm{T}_{\mathrm{e}}$ mode in which the electron temperature can reach $260 \mathrm{eV}$-three to four times higher than in a single-cell mirror for comparable input beam current-and a lower $T_{0}$ mode that is similar to a single-ceil mirror. Our initial research suggests that any shift between the two modes may be connected to vacuum conditions. Also, we noted that when heating the central-cell ions with neutral beams (during the high $T_{e}$ mode), the temperature in the plug elevated. 


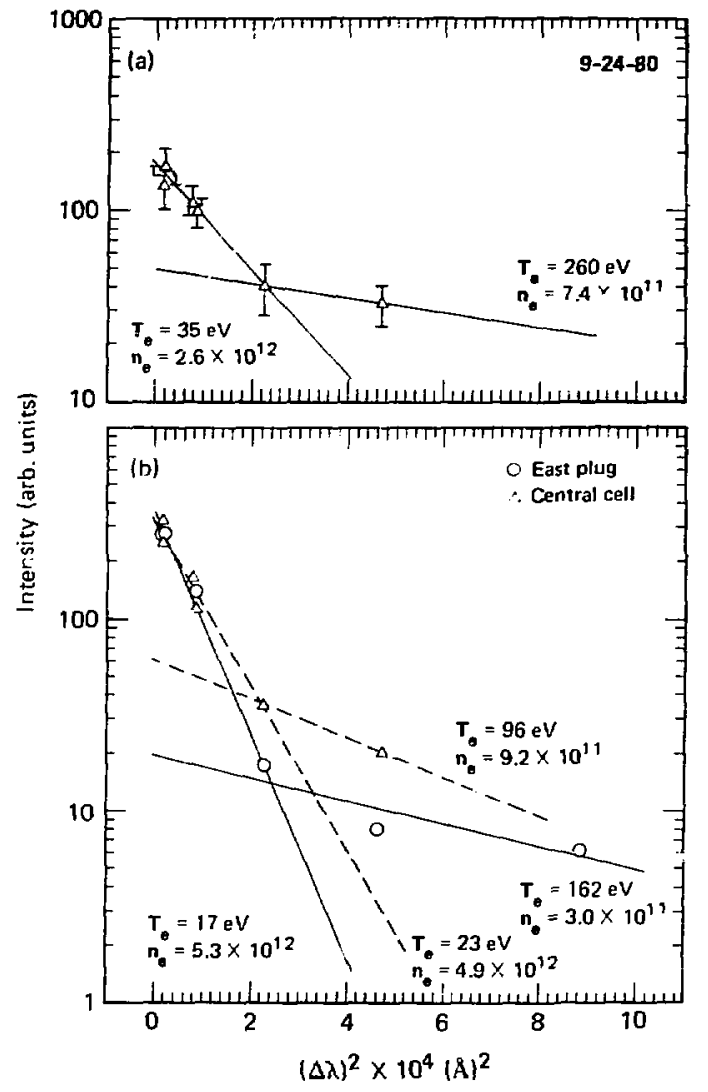

Figure 18. Tñomson-scattered light spectra indicating a b:-Maxweltian electron distribution: (a) central-cell specirum with plasma in equilibrium and (b) simultaneous east-plug and central-cell spectra taken 5 ms after the east-plug beams were terminaled. ( $\Delta \lambda$ is the shift from the laser wavelength.) The dashed lines are fits to the central-cell spectrum, and the solid lines are fits to the east-plug spectrum. 
Radial profiles of the plug electron temperature generafly follow a density-squared radial profile (as determined from other diagnostics) and are relatively flat to $r=5 \mathrm{~cm}$. Furthermore, the radial profile of the potential has a shape similar to the

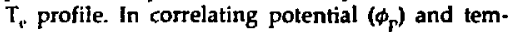
perature $\left(T_{e}\right)$, we have found that the ratio of $\phi_{F} / T_{b}$ in the plug ranges between four and six.
A comparison of $T_{e}$ in the plug and central cell shows that the electron temperature in the two regions is comparable, but that often $T_{p}$ is not constant along a magnetic iield line. In addition, we found that under some conditions there is an indication that a non-Maxwellian electron distribution may be present in both the end plug and the central cell. 


\section{References}

1. D. P. Grubb, 5. L. Allen, T. A. Casper, J. F. Clauser, P. Coakley, F. H. Coensgen, R. H. Cohen, D. L. Correll, W. C. Cummins, J. C. Davis, R. P. Drake, J. H. Foote, A. H. Futch, R. K. Goodman, G. E. Gryczkowski, G. A. Hallock, E. B. Hooper, Jr., R. S. Homady, A. L. Hunt, C. V. Karmendy, W. E. Nexsen, W. L. Pickles, G. D. Porter, P. Poulsen, T. D. Rognlien, T. C. Simonen, D. R. Slaughter, and O. T. Strand, Energy Confinememt Studies in TMX: Power Flow, Lawrence Livermore National Laboratory, Livermore, CA, UCRL-86476 (1981); submitted to Phys. Fluids.

2. D. P. Grubb, S. L. Allen, T. A. Casper, J. F. Clauser, F. H. Coensgen, D. L. Correll, W. C. Cummins, J. C. Davis, D. Dietrich, R. P. Drake, 1. H. Foote, R. J. Fortner, A. H. Futch, R. K. Goodman, G. E. Gryczkowski, G. A. Hallock, E. B. Hooper, Jr., R. S. Homady, A. L. Hunt, C. V. Kamendy, T. Nash, W. E. Nexsen, W. L. Pickles, G. D. Porter, P. Poulsen, T. C. Simonen, D. R. Slaughter, and O. T. Strand, Energy Confinement Studies in TMX: Pouter Balance, Lawrence Livermore National Laboratory, Livermore, CA, UCRL-86482 (1981); submitted to Phys. Fluids.

3. T. C. Simonen, C. A. Anclerson, T. A. Casper, J. F. Clauser, F. H. Coensgen, W. C. Condit, D. L. Correll, W. F. Cummins, ]. C. Davis, R. P. Drake, J. H. Foote, R. J. Fortnes, A. H. Futch, R. K. Goodman, D. P. Grubb, E. B. Hooper, Jr., R. S. Homady, A. L. Hunt, C. V. Karmendy, B. G. Logan, R. H. Munger, W. E. Nexsen, W. L. Pickles, P. Poulsen, D. R. Slaughier, B. W. Stallard, G. A. Hallock, and O. T. Strand, "Plasma Confinement Experiments in the TMX Tandem Mirsor," in Proc. 8th Intl. Conf. on Plasma Plys. and Controlled Nucl. Fusion Res., Brussels, 1980 (IAEA-CN-38/F-1. Vienna, 1981) Vol. 1, p. 97.

4. T. C. Simonen, "Introduction," in Summary of Results from the Tandem Mirror Experment (TMX), TMX Group and T. C. Simonen, Eds., Lawrence Livermore National Laboratory, Livermore, CA. UCRL-53120 (1981), p. 2-1.

5. F. H. Coensgen, TMX Major Project Proposal, Lawrence Livemore National Laboratory, Livermore, CA, LLL-Prop-148 (1977).

6. R. K. Goodman, J. F. Clauser, A. M. Frank, D. A. Goerz, and D. D. Lang. Thomsom-Scntermg Systcms on TMX, Lawrence Livermore National Laboratory, Livermore, CA, UCRL-53221 (1981).

7. T. C. Simonen, Comparison of Tandem Mirror Confinement with Single Mirror Experiments, Lawrence Livermore National Laboratory, Livermore, CA, UCRL-85834 (1981); submitted to Nucl. Fuston.

8. P. Coakley, N. Hershikowitz, and G. D. Porter, End Wall Plasma Characteristics in the Tandem Mirror Experiment, Lawrence Livermore National Laboratory, Livermore, CA, UCRL-85846 (1981); submitted to Nucl. Fusion.

9. D. L. Correll, R. K. Goodnan, W. E. Nexsen, and W. L. Pickles, "Summary of TMX Operations at High and Low Electron Temperatures," in Mirror Fusion Quartcrly Report, Octoher through December 1980, M. A. Harrison and C. K. McGiegor, Eds., Lawrence Livermore National Laboratory, Livermore, CA, UCAR-10060-80-4 (1980).

10. D. L. Correll, R. K. Goodman, and W. L. Pickles, "Effect of Vacium Conditions on Electron Temperature," in Summary of Rzsults from the Tandem Mirror Expcriment (TMX). TMX Group and T. C. Simonen, Eds., Lawrence Livermore National Laboratory, Livermore, CA, UCRL-53120 (1981), p. A-9.

11. D. L. Correll, S. L. Allen, T. A. Casper, J. F. Clauser, P. Coakley, F. H. Coensgen, W. Condit, W. C. Cummins, J. C. Davis, R. P. Drake, J. H. Foote, A. H. Futch, R. K. Goodman, D. P. Grubb, G. A. Hallock, E. B. Hooper, R. S. Homady, A. L. Hunt, C. V. Karmendy, A. W. Molvik, W. E. Nexsen, W. L. Pickles, P. Poulsen, T. C. Simonen, B. W. Stallard, and O. T. Strand, "Ambipolar Potentia! Formation and Axial Confinement in TMX," in Summary of Results from the Tandem Mirror Experin ent (TMX), TMX Group and T. C. Simonen, Eds., Lawrence Livermore National Laboratory, Li ermore, CA, UCRL-53120 (1981), p. 3-1.

12. S. L. Allen, C. A. Anderson, W. L. Barr, G. A. Burginyon, J. F. Clauser, P. Coakley, R. Crabb, W. F. Cummins, G. E. Davis, D. Dietrich, J. H. Foote, R. Fortner, A. M. Frank, C. E. Frerking, A. H. Futch, D. A. Goerz, R. K. Goodman, D. P. Grubb, G. A. Hallock, R. L. Hickok, E. B. Hooper, Jr., R. S. Hornady, A. L. Hunt, C. V. Karmendy, H. A. Koehler, G. W. Leppelmeier, M. E. McGee, R. H. Munger, T. Nash, W. E. Nexsen, L. B. Olk, M. P. Pat,, G. D. Porter, P. Poulsen, T. C. Simonen, D. R. Slaughter, H. D. Snyder, J. P. Stoering, O. T. Strand, and A. Toor, "TMX Diagnostics Instrumentation." in Summary of Results from the Tandem Mirror Experiment (TMX), TMX Group and T. C. Simonen, Eds., Lawrence Livermore National Laboratory, Livermore, CA, UCRL-53120 (1981), p. B-1. 
13. R. P. Drake, T. A. Casper, J. F. Clauser, F. H. Coensgen, D. L. Correll, W. F. Cummins, J. C. Davis, J. H. Foote, A. H. Futch, R. K. Goodman, D. P. Grubb, R. S. Hornady, W. E. Nexsen, T. C. Simonen, and B. W. Stallard, "The Effect of End-Cell Stability on the Confinement of the Central-Cell Plasma in TMX," Nucl. Fusion 21, 359 (1981).

14. T. D. Rognlien and Y. Matsuda, "Tandem Mirror Confinement in the Presence of Ion Cyclotron Fluctuations," Nucl. Fusion 21, 345 (1981).

15. F. H. Coensgen, C. A. Anderson, T. A. Casper, J. F. Clauser, W. C. Condit, D. L. Correll, W. F. Cummins, J. C. Davis, R. P. Drake, J. H. Foote, A. H. Futch, R. K. Goodman, D. P. Grubb, G. A. Hallock, R. S. Hornady, A. L. Hunt, B. G. Logan, R. H. Munger, ,V. E. Nexsen, T. C. Simonen, D. R. Slaughter, B. W. Stallard, and O. T. Strand, "Electrostatic Plasma-Confinement Experiments in a Tandem Mirror System," Pliys. Rev. Lett. 44, 1132 (1980).

16. J. F. Clauser, Lawrence Livermore National Laboratory, Livermore, CA, private communication (October 1979).

17. O. T. Strand, H. W. Moos, and S. L. Allen, Measurement of Impurity Concentrations and Raniated Pozuer in the Tandem Mirror Experiment Using Extreme Ulltraviolet \$yectroscopy, Lawrence Livermore National Laboratory, Livermore, CA, UCRL-86477 (1981); submitted to Nucl. Fusion.

18. S. L. Allen, O. T. Strand, H. W. Moos, R. J. Fortner, T. J. Nash, D. D. Dietrich, An Imptrity Study of $T M X$ Using Ultraviolet Spectroscopy, Lawrence Livermore National Laboratory, Livermore, CA, UCID-18883 (1981;.

19. S. E. Segre and L. Pieroni, "Measurement of Non-Maxwellian Eleciron Distribution Functions in Hot Plasma and the Importance for Thomson Scattering Diagnostics," Phus. Lett. 51A, 25 (1975).

20. D. L. Correll, Lawrence Livermore National Laboratory, Livemore, CA, privare communication (October 1981). 